\title{
Merintis ketahanan pangan dan membentuk karakter peduli lingkungan pada remaja di Piyungan
}

\author{
Astuti Wijayanti *, Laily Rochmawati Listiyani, Tias Ernawati, Rini Nurhayati \\ Program Studi Pendidikan IPA, Fakultas Keguruan dan Ilmu Pendidikan, Universitas Sarjanawiyata \\ Tamansiswa. Jalan Batikan UH-III/1043 Yogyakarta 55167, Indonesia \\ * Corresponding Author. Email: astuti.wijayanti@ustjogja.ac.id \\ Received: 14 August 2019; Revised: 3 October 2019; Accepted: 18 October 2019
}

\begin{abstract}
Abstrak
Cepokojajar Piyungan memiliki banyak potensi sumber daya manusia dengan usia produktif. Di sana juga terdapat banyak lahan yang digunakan untuk mengembangkan potensi lokal seperti pertanian. Kegiatan ini bertujuan untuk memberdayakan pemuda dengan kegiatan positif dan meningkatkan ketahanan pangan di daerah tersebut sehingga menjadi remaja yang mandiri, bermanfaat dan peduli terhadap lingkungan sekitar. Metode kegiatan ini praktik berkelompok, diskusi dan tanya jawab yaitu meliputi (1) praktek pembenihan tanaman pangan; (2) praktek membuat nutrisi tanaman dan pupuk cair dari bahan-bahan yang mudah didapatkan seperti air kelapa, susu fermentasi, telur, cangkang telur, dan kulit pisang; (3) teknik perawatan tanaman; dan (4) pemanfaatan barang bekas sebagai media tanam. Kegiatan ini bekerjasama dengan WALHI Yogyakarta dan karang taruna Cepokojajar Piyungan Bantul. Pengabdian masyarakat ini mendampingi remaja untuk praktik langsung dalam mengelola lingkungan yang efektif dan efisien sehingga dapat menumbuhkan karakter peduli lingkungan sejak dini bagi remaja. Peserta sangat antusias dan aktif selama kegiatan, mereka mendapatkan pengalaman dan pengetahuan aplikatif di bidang pertanian dan kesadaran untuk peduli terhadap lingkungannya semakin besar. Peserta termotivasi untuk praktik langsung di lingkungan masing-masing serta bertekad untuk mengembangkan pengetahuan yang mereka peroleh di rumah masing-masing dengan bertanam, merawat dan memanfaatkan produk pangan, sehingga remaja aktif merintis ketahanan pangan di daerah Piyungan.
\end{abstract}

Kata Kunci: ketahanan pangan, karakter peduli lingkungan.

\section{Pioneering food security and shaping the character of environmental care for adolescents in Piyungan}

\begin{abstract}
Cepokojajar Piyungan has a lot of potential human resources with productive age. There is also a lot of lands that are used to develop local potential such as agriculture. This activity aims to empower youth with positive activities and improve food security in the area so that they become adolescents who are independent, useful and care for the surrounding environment. The method of this activity is group practice, discussion and question and answer which includes (1) the practice of hatching food crops; (2) the practice of making plant nutrients and liquid fertilizer from easily available materials such as coconut water, fermented milk, eggs, eggshells, and banana peels; (3) plant care techniques; and (4) utilization of used goods as planting media. This activity is in collaboration with WALHI Yogyakarta and Cepokojajar Piyungan Bantul youth. This community service assists youths to practice directly in managing the environment effectively and efficiently to foster the character of caring for the environment early on for adolescents. Participants were very enthusiastic and active during the activity, they gained experience and applicative knowledge in agriculture and greater awareness to care for their environment. Participants are motivated to practice directly in their respective environments and are determined to develop the knowledge they obtain in their respective homes by planting, caring for and utilizing food products, so that young people actively pioneering food security in the Piyungan area.
\end{abstract}

Keywords: food security, environmental care character.

How to Cite: Wijayanti, A., Listiyani, L., Ernawati, T., \& Nurhayati, R. (2019). Merintis ketahanan pangan dan membentuk karakter peduli lingkungan pada remaja di Piyungan. JPPM (Jurnal Pendidikan dan Pemberdayaan Masyarakat), 6(2), 111-118. doi:https://doi.org/10.21831/jppm.v6i2.26656 
JPPM (Jurnal Pendidikan dan Pemberdayaan Masyarakat), 6 (2), 2019 - 112

Astuti Wijayanti, Laily Rochmawati Listiyani, Tias Ernawati, Rini Nurhayati

\section{PENDAHULUAN}

Ketahanan sistem pangan pada dasarnya memastikan kecukupan dan akses pangan untuk semua orang (Ali et al., 2018; Hapsari \& Rudiarto, 2017). Akses masyarakat untuk memperoleh pangan dan penyerapan pangan menjadi faktor penting dalam mewujudkan ketahanan pangan daerah (Hapsari \& Rudiarto, 2017). Menurut Suryani et al. (2019) keterampilan, pengalaman, pengetahuan, dan motivasi sangat diperlukan sehingga potensi daerah dapat dimanfaatkan secara sungguh-sungguh. Cepokojajar Sitimulyo Piyungan merupakan daerah pedesaan yang masih subur dan padat penduduk di RT o3 RW 23 sebanyak 77 kepala keluarga. Sebagian besar penduduknya berada pada usia produktif terutama remaja. Oleh karena itu, masyarakat Cepokojajar perlu dilibatkan secara aktif dalam pemanfaatan potensi daerah sehingga dapat lebih optimal dengan pembekalan keterampilan, pengalaman, pengetahuan dan motivasi tentang ketahanan pangan secara memadai.

Mayoritas penduduk di pedesaan bekerja di sektor pertanian. Dengan demikian, perkembangan pertanian di daerah pedesaan harus didukung dengan fasilitas yang baik dan memadai untuk menunjang pelaksanaan dan optimalisasi hasil produk pertanian. Apabila mayoritas penduduk desa dapat melaksanakan mobilitas ekonomi-sosial pembangunan maka dapat dipastikan kelangsungan ekonomi wilayah perkotaan berjalan lancar (Syaifullah, 2013). Berdasarkan hal tersebut, remaja di pedesaan menjadi salah satu sumber daya manusia yang sangat potensial untuk ikut serta terlibat dalam kegiatan pembangunan khususnya pada ketahanan pangan dan pelestarian lingkungan suatu daerah.

Menurut Fagi (2013), kebutuhan terhadap hasil pertanian, berupa pangan, akan terus bertambah seiring naiknya jumlah penduduk yang tidak terkendali. Sementara, konversi lahan pertanian produktif yang semakin marak dan tidak terkontrol dapat menyebabkan ketimpangan antara produksi pangan (supply) dan permintaan pangan (demand). Di samping itu, hal lain yang meresahkan saat ini terkait produksi pangan ada- lah penurunan produktivitas dan kualitas lahan pertanian terutama disebabkan oleh kandungan $\mathrm{C}$ organic dan unsur hara dalam tanah yang rendah, hal yang perlu dilakukan adalah mengembalikan bahan-bahan organik kedalam tanah melalui pupuk organik atau kompos (Sahwan et al., 2012).

Karakter peduli lingkungan merupakan salah satu karakter yang perlu dibangun dan dikembangkan baik di setiap jenjang pendidikan agar generasi masa depan memiliki tanggung jawab tinggi dalam berperan aktif menjaga pelestarian lingkungan. Karakter akan tercermin dalam tindakan atau tingkah laku sebagai manifestasi dari sifat-sifat jiwa manusia (pikiran, perasaan, dan kehendak) sekaligus penanda kepribadian seseorang yang khas, termasuk kaitannya dalam menyesuaikan diri dengan lingkungan (Afriyeni, 2018).

Anggita dan Supriyanto (2014) menyatakan bahwa integrasi nilai peduli lingkungan dalam suatu kegiatan dapat menjadi salah satu upaya dalam mencegah kerusakan pada lingkungan alam di sekitarnya, dan mengembangkan upaya untuk memperbaiki kerusakan alam yang terjadi. Oleh karena itu, nilai peduli lingkungan dapat dimulai dengan memperkenalkan remaja dengan lingkungan sekitar sebagai sumber belajar pelatihan. Pelatihan remaja ini dilakukan agar remaja mendapatkan kegiatan positif yang sekaligus dibekali karakter peduli lingkungan untuk dapat membangun ketahanan pangan di Piyungan.

Pengalaman dan pemahaman yang baik tentang lingkungan dikenalkan sejak usia dini, maka akan memberikan dampak yang positif dan akan membentuk karakter peduli lingkungan di masa yang akan datang (Mukminin, 2014). Remaja dapat memulai menerapkan di rumahnya dan dirinya sendiri sehingga selain dapat memenuhi kebutuhan rumahnya, remaja dapat hidup secara mandiri dan memiliki alternatif usaha. Manfaat kegiatan ini antara lain: Menambah pengetahuan tentang pelestarian alam melalui kegiatan pembibitan dan budidaya tanaman, remaja dapat memproduksi dan merawat tanaman bibit unggul dengan nutrisi yang baik, menumbuhkan karakter peduli lingkungan pada remaja sehingga dapat mening- 
JPPM (Jurnal Pendidikan dan Pemberdayaan Masyarakat), 6 (2), 2019 - 113

Astuti Wijayanti, Laily Rochmawati Listiyani, Tias Ernawati, Rini Nurhayati

katkan ketahanan pangan di Cepokojajar, dan memberikan lingkungan yang baik kepada remaja dengan mengajak untuk menjaga lingkungan sekitar dengan kegiatan positif.

Keberlanjutan ketahanan pangan perlu diperhatikan oleh seluruh elemen masyarakat diantaranya melalui ketersediaan pangan yang cukup dan memadai (Prabowo, 2010). Pemberdayaan masyarakat merupakan salah satu upaya untuk menyelesaikan permasalahan yang dihadapi oleh masyarakat dengan cara memberikan daya kepada masyarakat (Harahap, 2018). Secara mandiri, masyarakat perlu edukasi mengenai peran serta dalam ketahanan pangan. Upaya peningkatan produktivitas pertanian tidak hanya dilakukan oleh para petani melainkan bisa dilaksanakan di lingkungan rumah tangga.

Perilaku dan penanaman karakter peduli lingkungan perlu dibiasakan melalui program yang terprogram, berkelanjutan dan berkesinambungan. Apabila dalam lingkungan sekolah, rumah dan masyarakat sudah terlatih gaya hidup bersih dan sehat maka secara otomatis akan membentuk kepribadian mereka untuk menjaga dan melestarikan lingkungan. Tindakan sederhana dalam menjaga dan melestarikan lingkungan antara lain tidak membuang sampah sembarangan, tidak merusak tanaman, memperbanyak pembibitan dan pengelolaan sampah di lingkungan sekitar (Elsa et al., 2018).

\section{METODE}

Pemuda masa kini dikenal dengan istilah jaman now, lebih intens dengan penggunaan gadget dan jarang melakukan kegiatan yang berhubungan dengan aktivitas lingkungan terutama tanaman dan peluang usahanya. Lahan yang masih relatif luas namun kurang diberdayakan secara baik. Hal tersebut berakibat pada kurangnya kesadaran masyarakat khususnya remaja dengan perannya sebagai pemecah masalah di sekitarnya. Oleh karena itu, agar kesadaran remaja dapat terbangun dan dapat berperan aktif dalam merintis ketahanan pangan, maka tahapan kajian yang gunakan untuk menyelesaikan permasalahan pengabdian ini yaitu dengan memberikan pelatihan yaitu: (1) Pelatihan pembibitan dan budidaya tanaman; (2) Pendampingan dalam pembuatan nutrisi dan pupuk cair dan (3) penggunaan barang bekas untuk tempat media tanam.

Pelatihan remaja di Cepokojajar Piyungan ini dilaksanakan dengan cara praktik langsung, diskusi dan tanya jawab sehingga apa yang disampaikan dapat mudah dipahami oleh remaja. Metode tersebut dilaksanakan secara variatif sehingga tujuan kegiatan abdimas ini dapat tercapai. Untuk mendapatkan respon terhadap kegiatan ini, peserta mengisikan lembar evaluasi pengabdian. Pada hasil pengabdian ini akan dibahas secara kualitatif deskriptif.

\section{HASIL DAN PEMBAHASAN}

Pengabdian masyarakat ini dilaksanakan oleh Program Studi Pendidikan IPA Universitas Sarjanawiyata Tamansiswa Yogyakarta. Pelaksanaan pengabdian masyarakat ini dilaksanakan pada hari Rabu, 10 Juli 2019 pada pukul o8.30 s.d 12.00 WIB di Rumah salah satu warga RT o3 RW 23 Cepokojajar Piyungan Bantul Yogyakarta. Kegiatan ini diikuti oleh lima belas orang remaja usia sekolah menengah pertama (SMP) dan sekolah menengah kejuruan (SMK) yang terdiri atas empat orang remaja putra dan sebelas orang remaja putri.

Dalam pelaksanaan kegiatan, tim pengabdian menyusun suatu panduan berupa buku saku yang berisi petunjuk praktis pelaksaan kegiatan yang aplikatif sehingga dapat dipraktikkan peserta secara langsung. Buku saku yang berjudul "Penanaman Tanaman Pangan Ala Rumahan dan Merintis Social Entrepreneurship" disusun berdasarkan rangkaian kegiatan pelaksanaan program pengabdian. Secara umum berisi: (1) pembenihan tanaman pangan; (2) pembuatan nutrisi, pupuk cair, dan pestisida; (3) biopori dan pembuatan kompos; dan (4) pengelolaan hasil panen.

Pada kesempatan pertama, pelatihan ini memberikan arahan atau sosialisasi maksud dan tujuan kegiatan ini dilaksanakan. Kemudian dilanjutkan dengan membagi kelompok, terbentuk lima kelompok untuk memudahkan dalam kegiatan praktik pembibitan. Untuk memudahkan pelaksanaan tersebut, setiap remaja melaksanakan sesuai arahan draft buku saku. Dosen sebagai tim pengabdian masyarakat memberikan pelatih- 
JPPM (Jurnal Pendidikan dan Pemberdayaan Masyarakat), 6 (2), 2019 - 114

Astuti Wijayanti, Laily Rochmawati Listiyani, Tias Ernawati, Rini Nurhayati

an dan arahan bagaimana melakukan pembenihan tanaman pangan. Peserta diajak untuk menanam tanaman dari biji dan juga menanam dari buahnya. Pemilihan bibit akan menentukan kualitas tanaman yang akan ditanam. Metoda persemaian dapat dilakukan di lapangan terbuka atau pada bak kecambah, ataupun pot (Hanum, 2008).

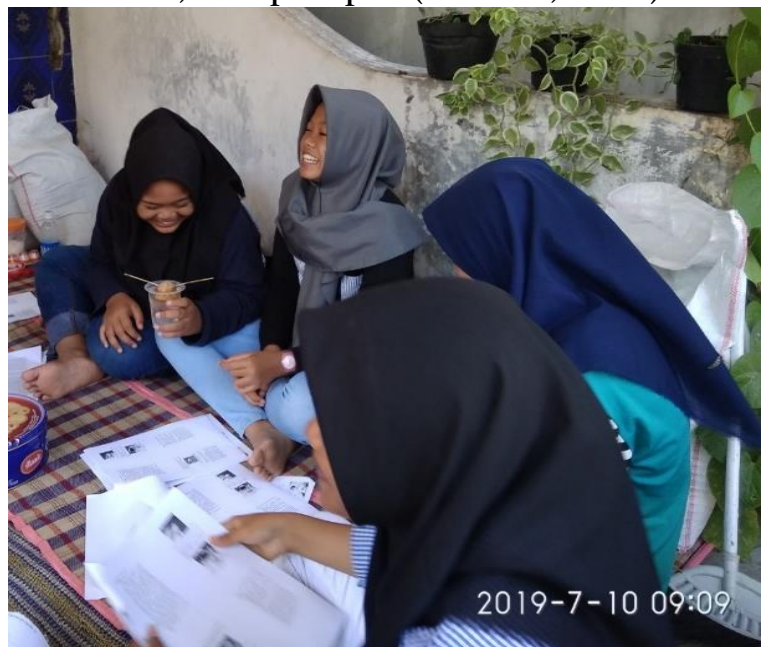

Gambar 1. Remaja melakukan diskusi

Tahap selanjutnya dilakukan praktik pembuatan nutrisi bagi tanaman, serta pembuatan pupuk dan pestisida cair dari bahanbahan yang mudah diperoleh di lingkungan peserta. Salah satu bahan yang digunakan adalah MSG (monosodium glutamate) atau lebih dikenal dengan istilah 'micin' oleh para peserta. Selain menambah cita rasa pada makanan fakta lain mengungkapkan bahwa MSG dapat digunakan sebagai pupuk pengganti berbagai pupuk kimia yang mudah ditemui dan mudah didapatkan peserta. Sebagaimana yang dikemukakan oleh Gresinta (2015) bahwa meningkatkan kualitas produksi tanaman kacang polong dilihat dari tinggi tanaman, menaikkan berat biji dan tanaman cepat berbunga. Manfaat MSG bagi tanaman diantaranya mempercepat pertumbuhan tanaman, daun lebih cepat menghijau, serta batang tanaman menjadi lebih cepat besar.

Kegiatan abdimas ini sangat bermanfaat dengan mempraktikkan pembudidayaan dan perawatan tanaman pangan yaitu dengan menggunakan pupuk dan nutrisi tanaman. Kecambah dipersemaian juga membutuhkan pemeliharaan dari serangan hama dan penyakit agar menjadi bibit tanaman yang sehat (Sito, 2014). Peserta diajak terampil dalam membuat nutrisi tumbuh bagi tanaman selain menggunakan MSG (monosodium glutamate) juga dari limbah kulit pisang dan cangkang telur.

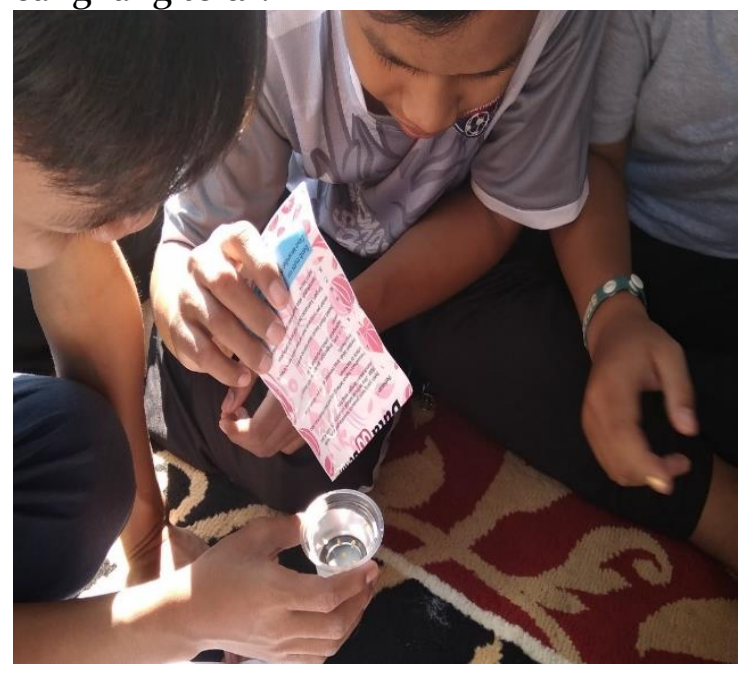

Gambar 2. Praktik menyemai cabe dengan peralatan yang sederhana

Stimulasi pertumbuhan buah dan bunga dapat juga diperoleh dari pengolahan limbah organik sisa rumah tangga sebagai nutrisi tanaman, diantaranya: potongan kulit pisang yang difermentasi. Menurut Machrodania et al. (2015) pemberian pupuk cair atau nutrisi berbahan kulit pisang dalam berbagai dosis berpengaruh sangat signifikan terhadap tinggi tanaman dan jumlah daun pada tanaman kedelai. Berdasarkan asumsi tersebut, maka tim dan peserta mencoba membuat nutrisi tanaman dengan bahan baku yang mudah diperoleh.

Nutrisi tanaman bisa diperoleh dengan memanfaatkan cangkang telur yang dihaluskan atau ditumbuk dapat untuk diaplikasikan seminggu sekali disemprotkan pada tanaman. Sebagaimana penelitian yang dilakukan oleh Rahmadina dan Tambunan (2017) menyatakan bahwa limbah cangkak telur dapat diolah menjadi pupuk organik dengan kadar unsur hara nitrogen, phosphor, dan kalium dalam kategori sedang, dan kandungan karbon atau senyawa organiknya sangat tinggi. Sehingga limbah cangkang telur dapat dikategorikan sebagai produk yang ramah lingkungan.

Sektor pertanian memiliki peranan penting bagi kelangsungan hidup, keharusan memenuhi kebutuhan pangan secara mandiri harus mulai dipikirkan. Kebijakan pangan 
JPPM (Jurnal Pendidikan dan Pemberdayaan Masyarakat), 6 (2), 2019 - 115

Astuti Wijayanti, Laily Rochmawati Listiyani, Tias Ernawati, Rini Nurhayati

dapat meningkatkan kemandirian pangan (Syaifullah, 2013). Dalam kegiatan ini, peserta juga dilatih mempersiapkan media tanam dan memberikan pupuk kandang untuk tempat tumbuh bibit. Media tanam yang baik tentunya akan sangat mempengaruhi pertumbuhan tanaman, oleh sebab itu media tanam harus dapat olah dengan baik (Sito, 2014).

Remaja diajak untuk memanfaatkan barang bekas baik karung, plastik dan botol minuman sebagai media tanam. Barang bekas tersebut dapat diperoleh dengan melakukan pemisahan sampah rumah tangga, menjadi sampah organik dan sampah anorganik. Sampah organik dapat dimanfaatkan sebagai kompos sedangkan sampah anorganik dimanfaatkan sebagai media tanam yang murah dan mudah didapat. Pemanfaatan sampah tersebut sebagai upaya efektif mengelola lingkungan dan membentuk karakter peserta agar peduli dengan lingkungan, sehingga tidak menjadi penyumbang sampah dan pencemaran tanah di sekitar wilayah Cepokojajar.

Sebagian besar peserta tidak mengetahui manfaat sampah organik dan pengolahannya untuk dapat dimanfaatkan kembali terutama sebagai nutrisi pertumbuhan tanaman. Pada pengabdian ini, remaja selain diarahkan dalam memanfaatkan sampah anorganik, juga diarahkan untuk memanfaatkan sampah rumah tangga yang organik. Setiap kelompok mendapatkan botol bekas yang akan digunakan sebagai tempat pembuatan nutrisi tumbuh. Selain itu, pemanfaatan sampah organik dalam pengabdian ini yaitu untuk pembuatan pupuk kompos. Untuk membantu merangsang pertumbuhan vegetatif dan generatif tanaman dapat dilakukan dengan memanfaatkan bahan sisa rumah (www.infoagribisnis.com). Pembuatan kompos dari limbah organik merupakan salah satu solusi praktis menyelesaikan permasalahan sampah dengan cara yang ramah lingkungan.

Menurut Hanum (2008), kompos sangat disarankan penggunaannya karena hasilnya lebih bagus. Kompos dapat dibuat dari macam-macam sisa tanaman (seperti jerami, serasah tanaman, dan bahan dari tanaman lainnya), dengan tambahan pupuk kandang bila ada. Daun pisang juga bisa menambah unsur potasium, daun-daun tanaman kacang-kacangan dapat menambah unsur $\mathrm{N}$, dan tanaman lain seperti Tithonia dan Afromomum angustifolium, memberikan tambahan unsur P.

Sahwan et al. (2012) mengemukakan bahwa keberhasilan penggunaan pupuk kompos dan pupuk organik yang berkualitas akan berimbang dengan kualitas dan produktivitas sumber daya lahan pertanian sehingga dapat meningkatkan dan memperkuat kemandirian pangan. Pemahaman tersebut harus disampaikan kepada remaja agar turut serta dalam kegiatan ketahan pangan dan pelestarian lingkungan.

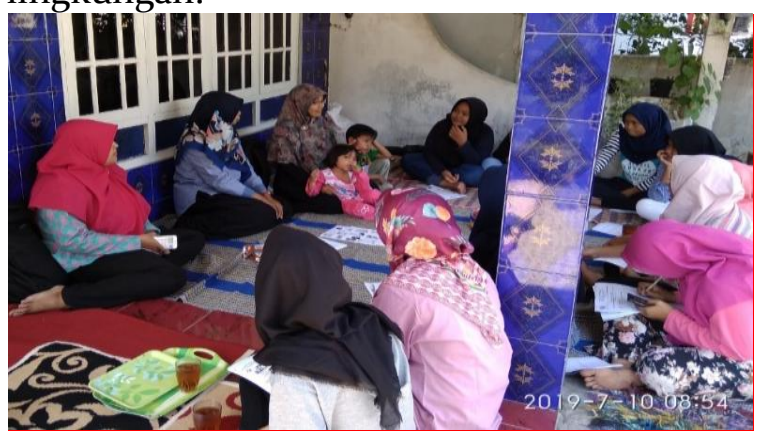

Gambar 3. Diskusi dengan tim abdimas Pendidikan IPA UST

Kegiatan praktik langsung yang dilakukan oleh peserta dalam mengolah sampah menjadi kompos dan menyiapkan nutrisi bagi tanaman menjadi menarik karena dikemas dalam aktivitas di luar ruangan dengan kebebasan eksplorasi dan interaksi langsung dengan lingkungan. Kegiatan ini selain membentuk kepribadian peduli lingkungan pada anak juga memupuk rasa tanggung jawab sebagai manusia untuk terus menjaga kelestarian lingkungan. Bentuk tanggung jawab tersebut melalui sikap menghargai dan menjaga lingkungan sekitar. Pemanfaatan lingkungan sekitar sebagai sumber belajar memungkinkan proses penanaman karakter lebih baik, penyampaian materi lebih menarik dan tidak membosankan (Ardianti et al., 2018).

Pada pengabdian ini, peserta juga diajak untuk dapat mempraktikkan pembuatan kompos pada lubang biopori. Peserta diberikan pengetahuan dan motivasi akan pentingnya biopori terhadap lingkungan. Pembuatan lubang biopori merupakan solusi teknologi 
JPPM (Jurnal Pendidikan dan Pemberdayaan Masyarakat), 6 (2), 2019 - 116

Astuti Wijayanti, Laily Rochmawati Listiyani, Tias Ernawati, Rini Nurhayati

ramah lingkungan untuk mengatasi ketersediaan air tanah dengan memanfaatkan sampah organik melalui lubang kecil dalam tanah. Dengan memanfaatkan teknologi tersebut maka wilayah perkotaan yang terlihat kering dan gersang atau yang rapat dengan bangunan akan berubah menjadi wilayah yang ramah lingkungan. Di samping itu, sampah organik yang tersimpan di dalam lubang dapat diolah dan dijadikan sebagai sumber penghasil kompos yang berguna untuk menyuburkan tanaman.

Biopori adalah pori-pori berukuran kecil yang dibuat oleh aktivitas fauna tanah atau akar tanaman. Lubang Resapan Biopori (LRB) adalah lubang dengan diameter 10-30 $\mathrm{cm}$ dengan panjang 30-100 $\mathrm{cm}$ yang ditutupi sampah organik, ditemukan oleh peneliti dan dosen Ilmu Tanah dan Sumber Daya Lahan dari IPB bernama Dr. Kamir Raziudin Brata. LRB berfungsi untuk menjebak air yang mengalir di sekitarnya sehingga dapat menjadi sumber cadangan air bagi air bawah tanah, tumbuhan di sekitarnya, serta membantu pelapukan sampah organik menjadi kompos untuk pupuk tanaman (www.biopori.com). Menurut penelitian dosen pertanian IPB, Kamir R Brata pada tahun 2006 lubang resapan biopori dapat mencegah banjir dengan memanfaatkan sampah organik (Brata \& Nelistya, 2008). Adanya biopori akan meningkatkan kemampuan tanah dalam meresapkan air sehingga memperkecil peluang terjadinya aliran air di permukaan tanah (www.biopori.com).

Air adalah sesuatu yang sangat dibutuhkan dan keberadaannya bisa sangat membahayakan ketika terjadi banjir. Sementara sampah adalah sumber daya yang dapat diolah menjadi produk yang bermanfaat, tetapi terkadang sampah menjadi sumber pencemaran bahkan merupakan penyebab banjir jika pembuangannya dilakukan secara sembarangan. Air sangat dibutuhkan oleh makhluk hidup. Makhluk hidup menyerap hampir 50\% dalam tubuhnya. Selain membutuhkan air, makhluk hidup membutuhkan oksigen dan makanan.

Tumbuhan atau tanaman membutuhkan makanan dan energi yang diserap melalui akar yang ada di tanah. Proses penyerapan ini akan sempurna apabila kandungan air dalam tanah cukup dan tidak berlebihan (Kurniastuti, 2010). Jika air tanah masih utuh, maka kerja makhluk di tanah ini akan mengganti air yang hilang karena penguapan oleh tanaman dan manusia, dan perlahan muncul sumber air baru yang akan dialirkan ke sungai atau danau serta dapat mendorong air asin untuk tidak masuk ke daratan. Hal ini dapat terjadi jika air cukup diserap oleh tanah (Maryati et al., 2016).

Seluruh rangkaian kegiatan abdimas akan dapat terus terlaksana apabila seluruh aktivitas terjadwal dan dikelola dengan baik. Oleh karena itu, untuk memudahkan remaja dalam mempraktikkan di rumah masingmasing perlu adanya suatu panduan pengelolaan sampah dan pembuatan pupuk maupun nutrisi bagi tanaman yang disusun agar mereka mudah mengikuti alur kegiatannya. Panduan tersebut tersusun dan diserahkan pada remaja untuk dapat dipelajari dan disampaikan pada sesama teman atau anggota keluarga. Selaras dengan penelitian yang dilakukan oleh Yulianti et al. (2014) yang menyatakan bahwa pengembangan karakter peduli lingkungan dapat dilakukan melalui media buku cerita yang berisi dengan konten sains sehingga dapat memberikan wawasan dan pengetahuan konservasi pada anak sejak dini.

Mereka antusias dalam mengikuti kegiatan pengabdian ini dari awal hingga pengabdian ini selesai. Berdasarkan hasil pengisian lembar evaluasi kegiatan dengan pertanyaan terbuka, peserta menyampaikan bahwa mereka sangat tertarik dan senang mendapatkan ilmu baru yang aplikatif. Respon peserta sangat positif terhadap kegiatan ini ditandai dengan beberapa komentar peserta yang menyatakan bahwa kegiatan menyenangkan, menambah pengetahuan dan pengalaman, serta menambah rasa peduli lingkungan melalui mengolah sampah menjadi hal yang bermanfaat khususnya ikut serta dalam bidang ketahanan pangan. Mereka bertekad untuk dapat memulai dan merintis ketahanan pangan dengan menerapkan apa yang sudah dilatihkan dalam kegiatan ini di rumah mereka masing-masing.

Ketahanan pangan dapat berhasil jika kesadaran akan peran masing-masing individu dalam masyarakat sudah terbentuk 
JPPM (Jurnal Pendidikan dan Pemberdayaan Masyarakat), 6 (2), 2019 - 117

Astuti Wijayanti, Laily Rochmawati Listiyani, Tias Ernawati, Rini Nurhayati

untuk melestarikan lingkungannya. Pemberdayaan remaja menjadi salah satu upaya untuk merintis peningkatan taraf hidup dan masyarakat yang sejahtera secara fisik, mental maupun sosial. Menurut (Suryani et al., 2019) Pendekatan yang digunakan dalam merintis ketahanan pangan yang menjadi salah satu prioritas dalam pembangunan di Indonesia harus senantiasa mengutamakan proses daripada hasil karena melalui proses tersebut dapat memanusiakan manusia. Proses yang memanusiakan manusia maksudnya adalah melibatkan masyarakat dalam pembangunan lebih mengarah kepada bentuk partisipasi.

Ketahanan pangan yang dirintis melalui kegiatan pengabdian ini juga dapat diketahui peserta dengan menyampaikan beberapa contoh pemanfaatan produk pertanian yang dapat dijadikan produk usaha maupun produk pangan sehingga kegiatan tersebut dapat bermanfaat dan memotivasi remaja.

\section{SIMPULAN}

Kegiatan pengabdian ini terlaksana dengan lancar dan antusias. Melalui praktik, remaja di Cepokojajar lebih mudah dalam memahami materi pengabdian. Antusiasme yang muncul pada diri remaja cepokojajar dapat memberikan kesadaran akan pentingnya kegiatan positif ini dalam perintisan ketahanan pangan di Piyungan. Kegiatan ini hendaknya dapat dilakukan dan diinternalisasikan dalam pembelajaran di sekolah sehingga tidak hanya sekedar materi tetapi juga dapat dipraktikkan dan menjadi kecakapan hidup bagi remaja. Melalui pengabdian ini, direkomendasikan perlunya RT, RW, Dusun untuk secara intensif menjalin kerja sama dengan universitas, dan LSM Lingkungan hidup sehingga dapat merintis dan semakin menguatkan ketahanan pangan di Piyungan. Kerjasama tersebut dapat menguatkan komitmen semua warga dalam menjaga lingkungan dan juga meningkatkan ketahanan pangan di Piyungan.

\section{DAFTAR PUSTAKA}

Afriyeni, Y. (2018). Pembentukan karakter anak untuk peduli lingkungan yang ada di Sekolah Adiwiyata Mandiri SDN 6 Pekanbaru. PAUD Lectura: Jurnal
Pendidikan Anak Usia Dini, 1(2), 123-133. https://doi.org/10.31849/paudlectura.v1 i2.1171

Ali, M. N., Mahfudz, M., Ramlan, R., \& Rahman, N. (2018). Sociopsicological rehabilitation model and the improvement of affected household food security in the terrorist's territory of Mt. Biru, Poso, Central Sulawesi. Social Humanity: Jurnal Ilmu Sosial Dan Humaniora, 2(2), 1-12. http://jurnal.untad.ac.id/jurnal/index. $\mathrm{php} / \mathrm{JH} /$ article/view/11771

Anggita, Y. D., \& Supriyanto. (2014). Penanaman dan pengembangan karakter peduli lingkungan di sekolah alam (Studi kasus di SMP Alam ArRidho Semarang). Journal of Biology Education, 3(3), 338-344. https://journal.unnes.ac.id/sju/index.p hp/ujbe/article/view/4534

Ardianti, F. E., Qomariah, N., \& Wibowo, Y. G. (2018). Pengaruh motivasi kerja, kompensasi dan lingkungan kerja terhadap kepuasan kerja karyawan (Studi kasus pada PT. Sumber Alam Santoso Pratama Karangsari Banyuwangi). Jurnal Sains Manajemen Dan Bisnis Indonesia, 8(1), 13-31. https://doi.org/10.32528/smbi.v8i1.1764

Brata, K. R., \& Nelistya, A. (2008). Lubang resapan biopori. Niaga Swadaya.

Elsa, F., Khairil, K., \& Yunus, Y. (2018). Penerapan pendidikan karakter peduli lingkungan melalui metode inkuiri terhadap sikap dan perilaku siswa pada materi pencemaran dan kerusakan lingkungan di SMP Negeri 6 Banda Aceh. BIOTIK: Jurnal Ilmiah Biologi Teknologi Dan Kependidikan, 2(1), 2832.

https://doi.org/10.22373/biotik.v2i1.232

Fagi, A. M. (2013). Ketahanan pangan indonesia dalam ancaman. Analisis Kebijakan Pertanian, 11(1), $11-25$. https://doi.org/10.21082/akp.v11n1.2013. 11-25

Gresinta, E. (2015). Pengaruh pemberian monosodium glutamat (MSG) terhadap pertumbuhan dan produksi kacang tanah (Arachis hypogea L.). Faktor Exacta, 8(3), 208-219. 
JPPM (Jurnal Pendidikan dan Pemberdayaan Masyarakat), 6 (2), 2019 - 118

Astuti Wijayanti, Laily Rochmawati Listiyani, Tias Ernawati, Rini Nurhayati

https://doi.org/10.30998/faktorexacta.v

$8 \mathrm{i} 3.322$

Hanum, C. (2008). Teknik budidaya tanaman.

Direktorat Pembinaan Sekolah

Menengah Kejuruan. Direktorat Jenderal Manajemen Pendidikan Dasar dan Menengah, Departemen Pendidikan Nasional.

Hapsari, N. I., \& Rudiarto, I. (2017). Faktorfaktor yang mempengaruhi kerawanan dan ketahanan pangan dan implikasi kebijakannya di Kabupaten Rembang. Jurnal Wilayah Dan Lingkungan, 5(2), 125-140.

https://doi.org/10.14710/jwl.5.2.125-140

Harahap, F. I. N. (2018). Dampak pemberdayaan masyarakat melalui program biogas dalam mewujudkan kemandirian energi. JPPM (Jurnal Pendidikan Dan Pemberdayaan Masyarakat), 5(1), 42-52. https://doi.org/10.21831/jppm.v5i1.1863 4

Kurniastuti, E. R. (2010). Minat siswa pada pengajaran remedial ditinjau dari dukungan sosial keluarga dan konsep diri akademik. Unika Soegijapranata Semarang.

Machrodania, M., Yuliani, Y., \& Ratnasari, E. (2015). Pemanfaatan pupuk organik cair berbahan baku kulit pisang, kulit telur dan Gracillaria Gigas terhadap pertumbuhan tanaman kedelai var Anjasmoro. Jurnal Lentera Bio. ISSN, 4(3), 168-173. https://jurnalmahasiswa.unesa.ac.id/in dex.php/lenterabio/article/view/13255

Maryati, M., Iryani, I., \& Amelia, F. (2016). Karakterisasi plastik biodegradable Nata de Soya menggunakan Plasticizer Asam Oleat. Sainstek: Jurnal Sains Dan Teknologi, 6(1), 65-70. https://doi.org/10.31958/js.v6i1.105

Mukminin, A. (2014). Strategi pembentukan karakter peduli lingkungan di sekolah Adiwiyata mandiri. Ta'dib: Journal of Islamic Education (Jurnal Pendidikan
Islam), $\quad$ 19(2), $\quad$ 227-252. https://doi.org/10.19109/tjie.v19io2.16

Prabowo, R. (2010). Kebijakan pemerintah dalam mewujudkan ketahanan pangan di Indonesia. Mediagro, 6(2), 62-73. https://doi.org/10.31942/md.v6i2.881

Rahmadina, R., \& Tambunan, E. P. S. (2017). Pemanfaatan limbah cangkang telur, kulit bawang dan daun kering melalui proses sains dan teknologi sebagai alternatif penghasil produk yang ramah lingkungan. KLOROFIL: Jurnal Ilmu Biologi Dan Terapan, 1(1). http://jurnal.uinsu.ac.id/index.php/klo rofil/article/view/1575

Sahwan, M. A., Ab Rahman, M. N., \& Deros, B. M. (2012). Barriers to implement lean manufacturing in Malaysian automotive industry. Jurnal Teknologi, 59(2), 107-110. https://doi.org/10.11113/jt.v59.2571

Sito, J. (2014). Pekarangan produktif \& $100 \%$ organik.

https://lsmorganik.files.wordpress.co $\mathrm{m} / 2014 / \mathrm{o8} /$ pekarangan-produktif.pdf

Suryani, D., Kurniawan, D., Melizan, D. S., \& Putra, G. (2019). Pemberdayaan masyarakat Dusun Jaten, Mrico dan Bruno 1 untuk meningkatkan ketahanan pangan dengan pemanfaatan potensi lokal. Jurnal Pemberdayaan: Publikasi Hasil Pengabdian Kepada Masyarakat, 3(1), 39-44.

https://doi.org/10.12928/jp.v3i1.6o8

Syaifullah, Y. (2013). Ketahanan pangan dan pola distribusi beras di propinsi jawa timur. JEJAK: Jurnal Ekonomi Dan Kebijakan, 6(2), 103-111. https://doi.org/10.15294/jejak.v6i2.3881

Yulianti, D., Rida, N. S., \& Diana, D. (2014). Pengembangan karakter peduli lingkungan anak usia dini melalui buku cerita bermuatan sains berwawasan konservasi. Jurnal Penelitian Pendidikan, $31(1)$. https://doi.org/10.15294/jpp.v31i1.5681 